\title{
The role of the outer membrane in formaldehyde tolerance in Escherichia coli VU3695 and Halomonas sp. MAC
}

\author{
Malkit Azachi, ${ }^{1}$ Yigal Henis, ${ }^{1}$ Roni Shapira ${ }^{2}$ and Aharon Oren ${ }^{3}$ \\ Author for correspondence: Malkit Azachi. Tel: +972 8 481165. Fax: +972 8466794. \\ e-mail: azachi@agri.huji.ac.il
}

1 Department of Plant Pathology and Microbiology, and Otto Warburg Center for Biotechnology in Agriculture, Faculty of Agriculture, The Hebrew University of Jerusalem, Rehovot 76100, Israel

2 Department of Biochemistry and Food Science, Faculty of Agriculture, The Hebrew University of Jerusalem, Rehovot 76100, Israel

3 Division of Microbial and Molecular Ecology, Institute of Life Sciences and Moshe Shilo Center for Marine Biogeochemistry, The Hebrew University of Jerusalem, Jerusalem 91904, Israel

\begin{abstract}
To investigate the mechanism of formaldehyde tolerance in Gram-negative bacteria, two formaldehyde-tolerant strains, Escherichia coli VU3695 and Halomonas sp. MAC (DSM 7328), and formaldehyde-sensitive revertants obtained by ethidium bromide or novobiocin treatment were studied. The presence of high levels of formaldehyde dehydrogenase activity alone proved insufficient to confer tolerance to high formaldehyde concentrations, as shown by the high activity displayed by formaldehyde-sensitive revertants of Halomonas MAC. Moreover, formaldehyde-tolerant strains also proved to be tolerant to high concentrations of acetaldehyde and glutaraldehyde, which are not oxidized by formaldehyde dehydrogenase. Treatment with sublethal concentrations of EDTA rendered the resistant strains highly sensitive to formaldehyde without affecting the activity of formaldehyde dehydrogenase. Comparison of the outer membrane proteins of formaldehyde-resistant strains with those of their sensitive revertants showed the presence of at least one additional high molecular mass protein in the tolerant strains. It is concluded that formaldehyde tolerance in the bacteria studied depends on the composition and structure of the outer membrane.
\end{abstract}

Keywords: Escherichia coli, Halomonas sp., formaldehyde, outer membrane, tolerance

\section{INTRODUCTION}

In recent years a number of reports have appeared on the occurrence of bacteria resistant to high concentrations of formaldehyde. Strains of Eschericbia coli and Serratia marcescens tolerating formaldehyde concentrations of 500 and 200 p.p.m., respectively, have been isolated (Kaulfers \& Marquardt, 1991; Kaulfers \& Laufs, 1985). Likewise, highly formaldehyde-tolerant strains of Pseudomonas putida and Halomonas sp. have been characterized (Azachi et al., 1995; Kato et al., 1984, 1986).

One of the factors that may play a role in conferring formaldehyde tolerance in bacteria is the presence of intracellular enzymes metabolizing formaldehyde. Thus, high levels of activity of an NAD- and glutathionedependent formaldehyde dehydrogenase (EC 1.2.1.1) were demonstrated in formaldehyde-resistant strains of $E$. coli, S. marcescens, and Halomonas sp. (Azachi et al., 1995; Kaulfers \& Marquardt, 1991; Kaulfers \& Laufs, 1985). Additional enzymes, such as formaldehyde dismutase (EC
1.2.99.4) and dye-linked formaldehyde dehydrogenase (EC 1.2.99.3) may be involved in the detoxification of formaldehyde in other micro-organisms (Kato et al., 1984, 1986, 1988). In certain bacteria at least, the property of formaldehyde tolerance may be plasmid-mediated (Kaulfers \& Brandt, 1987; Kaulfers \& Laufs, 1985).

In the present work we investigated the possible role of the outer membrane of Gram-negative bacteria in formaldehyde resistance. The outer membrane is the primary barrier that formaldehyde molecules encounter when interacting with these bacteria. The outer membrane has been shown to act as a molecular sieve which determines, mainly on the basis of molecular size, whether or not a substrate can enter the cell (Lieve, 1974; Nikaido \& Vaara, 1985). To our knowledge, the role of the outer membrane in formaldehyde tolerance has not previously been investigated. We present evidence that the properties of the outer membrane are of prime importance in conferring formaldehyde tolerance in $E$. coli and in a Halomonas isolate. 


\section{METHODS}

Bacterial strains and culture conditions. The formaldehydetolerant strain Escherichia coli VU3695 (Kaulfers \& Marquardt, 1991), which harbours a $94 \mathrm{~kb}$ plasmid, was grown at $37^{\circ} \mathrm{C}$ with constant gyratory shaking at 150 r.p.m. in Luria broth medium (LB) (Sambrook et al., 1989) or in nutrient broth (NB). Formaldehyde-sensitive revertants (strain VU3695-21 and VU3695-31) were isolated by random mutagenesis in the presence of ethidium bromide, as described by Kaulfers \& Brandt (1987). Halomonas elongata ATCC 33173 and Halomonas sp. MAC (DSM 7328), which show high levels of formaldehyde resistance (Azachi et al., 1995), were grown at $30^{\circ} \mathrm{C}$ with constant gyratory shaking at 150 r.p.m. in LB or NB medium supplemented with $10 \%(\mathrm{w} / \mathrm{v}) \mathrm{NaCl}$. Three revertant strains of Halomonas MAC, which itself harbours a $15 \mathrm{~kb}$ plasmid, were obtained by treatment with novobiocin as described below: MAC-29, a formaldehyde-tolerant strain lacking the plasmid, MAC-6, a formaldehyde-sensitive strain lacking the plasmid, and MAC-2, a sensitive strain containing the plasmid.

Growth inhibition by formaldehyde, acetaldehyde and glutaraldehyde. Overnight cultures of E. coli VU3695, and Halomonas MAC and mutants as indicated above were grown in $\mathrm{NB}$ medium and $10 \% \mathrm{NaCl}$-supplemented $\mathrm{NB}$ medium, respectively. They were then harvested by centrifugation $(12000 \mathrm{~g}$ at $4{ }^{\circ} \mathrm{C}$ for $\left.10 \mathrm{~min}\right)$. Cells were resuspended in the growth medium to an $\mathrm{OD}_{540}$ of 0.03 and cultures were amended with formaldehyde $[37 \%, v / v$, solution containing $10 \%, v / v$, methanol (Merck)], or acetaldehyde or glutaraldehyde at concentrations up to 500 p.p.m. Triplicate portions $(5 \mathrm{ml}$ in $20 \mathrm{ml}$ test tubes) were incubated aerobically at 37 or $30^{\circ} \mathrm{C}$, respectively, and after $48 \mathrm{~h}$ the $\mathrm{OD}_{540}$ was measured.

Effect of formaldehyde and EDTA on cell viability. Cells were harvested in the early to mid-exponential growth phase by centrifugation $\left(12000 \mathrm{~g}\right.$ for $10 \mathrm{~min}$ at $\left.4{ }^{\circ} \mathrm{C}\right)$. To test the effect of sublethal EDTA concentrations on sensitivity to killing by formaldehyde, cells were washed twice with $10 \mathrm{mM}$ Tris $/ \mathrm{HCl}$ buffer, $\mathrm{pH} 8.0$, containing $0.9 \% \mathrm{NaCl}$ (for E. coli) or $10 \% \mathrm{NaCl}$ (for Halomonas), and resuspended to a final $\mathrm{OD}_{540}$ of 0.055 in $30 \mathrm{ml}$ of the appropriate buffer containing $1 \mathrm{mM}$ or $0.5 \mathrm{mM}$ EDTA, respectively. In control experiments EDTA was omitted. Suspensions were incubated at the growth temperature for $1 \mathrm{~h}$, followed by washing twice in buffer without EDTA and suspension in buffer. Formaldehyde ( 25 or 1000 p.p.m.) was added, and after $1 \mathrm{~h}$ of incubation at the growth temperature the cultures were decimally diluted and the number of c.f.u. counted on $\mathrm{LB}$ agar with or without $10 \% \mathrm{NaCl}$ as required, and compared with the number in the absence of formaldehyde. Similar experiments were performed with acetaldehyde (15 or 500 p.p.m.) or glutaraldehyde (25 or 1000 p.p.m.).

Isolation and characterization of outer membrane and cytoplasmic proteins. The outer membrane and the cytoplasmic fraction were isolated according to the following protocol, based in part on methods described by Hancock \& Nikaido (1978), McGavin et al. (1990) and Wang \& Thomson (1990). Cultures $(500 \mathrm{ml})$ in the late exponential growth phase were supplemented with $\mathrm{NaCl}$ and Tris/ $\mathrm{HCl}$ buffer, $\mathrm{pH} 7 \cdot 3$, to a final concentration of $33 \mathrm{mM}$ each. After $10 \mathrm{~min}$ incubation at $25^{\circ} \mathrm{C}$, cells were harvested by centrifugation and resuspended in $33 \mathrm{mM}$ Tris $/ \mathrm{HCl}$ buffer, $\mathrm{pH} 7 \cdot 3$, to a density of $100 \mathrm{mg}$ wet cell wt $\mathrm{ml}^{-1}$. An equal volume of buffer consisting of $33 \mathrm{mM}$ Tris $/ \mathrm{HCl}, 40 \%$ (w/v) sucrose and $2 \mathrm{mM}$ EDTA, $\mathrm{pH} 7 \cdot 3$, was added, and after an additional centrifugation, cells were suspended in ice-cold $1 \mathrm{mM} \mathrm{MgCl}$ ( $50 \mathrm{mg}$ wet wt ml ${ }^{-1}$ ) and incubated at $-20{ }^{\circ} \mathrm{C}$ for $10 \mathrm{~min}$, followed by $10 \mathrm{~min}$ centrifugation at $10000 \mathrm{~g}$ at $4^{\circ} \mathrm{C}$. Cells were washed once in PBS
(3.3 mM NaH $\mathrm{PO}_{4}, 6.7 \mathrm{mM} \quad \mathrm{Na}_{2} \mathrm{HPO}_{4}, 126.5 \mathrm{mM} \mathrm{NaCl}$, $\mathrm{pH} 7 \cdot 0$ ), resuspended in the same buffer, and disrupted by two passages through a French press cell in the cold. The lysate was centrifuged at $16300 \mathrm{~g}$ for $30 \mathrm{~min}$ at $4{ }^{\circ} \mathrm{C}$. Ten millilitres of the supernatant was subsequently centrifuged at $30500 \mathrm{~g}$ for $2.5 \mathrm{~h}$ at $4{ }^{\circ} \mathrm{C}$ and the supernatant was collected (cytoplasmic fraction). Another $10 \mathrm{ml}$ portion of the supernatant was diluted by the addition of $10 \mathrm{ml}$ of Tris buffer and $6 \mathrm{ml}$ was layered on top of a sucrose step gradient consisting of $1 \mathrm{ml} 70 \%$ sucrose in Tris buffer on the bottom and $6 \mathrm{ml}$ of $15 \%$ sucrose in Tris buffer on top, and the tubes were centrifuged at $121500 \mathrm{~g}$ for $2.5 \mathrm{~h}$ at $4{ }^{\circ} \mathrm{C}$. The bottom $2 \mathrm{ml}$ of each gradient was removed, and each $2 \mathrm{ml}$ was applied to another sucrose density gradient containing $5 \mathrm{ml}$ of $60 \%$ sucrose in Tris buffer in the bottom layer and $5 \mathrm{ml}$ of $47 \%$ sucrose in Tris buffer in the top layer. Tubes were centrifuged for $6 \mathrm{~h}$ at $121500 \mathrm{~g}$. The lower outer membrane band was collected, diluted in distilled water and centrifuged at $30500 \mathrm{~g}$ for $2.5 \mathrm{~h}$ at $4{ }^{\circ} \mathrm{C}$. The resulting pellet was washed twice with PBS and resuspended at $4^{\circ} \mathrm{C}$ in $10 \mathrm{ml} 50 \mathrm{mM}$ Tris $/ \mathrm{HCl}$ containing $1 \mathrm{mM} \mathrm{MgCl}$ and $0.2 \mathrm{mM}$ DTT, $\mathrm{pH} 8 \cdot 0$.

Protein was determined by the method of Bradford (1976), with BSA as a standard.

Proteins were separated by electrophoresis in SDS-PAGE gels $[10 \%(\mathrm{w} / \mathrm{v})$ acrylamide], and stained with Coomassie brilliant blue G250, using standard methods (Hancock \& Carey, 1979). The molecular masses of the proteins were estimated by using low-range prestained standards (Bio-Rad Laboratories), which included the following proteins: phosphorylase $B$ $(142.9 \mathrm{kDa})$, bovine serum albumin $(97 \cdot 2 \mathrm{kDa})$, ovalbumin $(50 \mathrm{kDa})$, carbonic anhydrase $(35 \mathrm{kDa})$, soybean trypsin inhibitor $(29.7 \mathrm{kDa})$ and lysozyme $(21.9 \mathrm{kDa})$.

Plasmid isolation, transformation and curing. Plasmid DNA was isolated as described by Birnboim \& Doly (1979) or using the QIAGEN plasmid kit (Hildan). Plasmids or their $N b e I$ digests were analysed on $0.8 \%$ agarose gels, followed by ethidium bromide staining and UV-visualization (Sambrook et al., 1989). The molecular masses of the plasmid fragments were estimated by comparison with DNA ladder fragments. Plasmid transformation was performed by chemical treatment (Sambrook et al., 1989) or by electroporation (Diver et al., 1990). Halomonas MAC was cured of its plasmid by growing the bacteria for $24 \mathrm{~h}$, transferring every $8 \mathrm{~h}$ in LB medium containing $5 \mu \mathrm{g}$ novobiocin $\mathrm{ml}^{-1}$. Inoculum size was 1,5 and $10 \%$ $(\mathrm{v} / \mathrm{v})$ for the first, second and third transfers, respectively: Bacteria surviving the curing treatment were centrifuged for $10 \mathrm{~min}$ at $10000 \mathrm{~g}$ at $4{ }^{\circ} \mathrm{C}$, washed twice with $10 \% \mathrm{NaCl}$ medium and then plated on $10 \% \mathrm{NaCl}$-containing LB agar plates without formaldehyde or with 20 or 50 p.p.m. formaldehyde. Plasmid curing of E. coli VU3695 was performed using 1.8 mg ethidium bromide $\mathrm{ml}^{-1}$ (Kaulfers \& Brandt, 1987).

Formaldehyde dehydrogenase assays. NAD- and glutathionedependent formaldehyde dehydrogenase was assayed spectrophotometrically as described previously (Azachi et al., 1995; Kaulfers \& Marquardt, 1991). The formaldehyde concentration in the reaction mixture was $0 \cdot 1 \mathrm{mg} \mathrm{ml}^{-1}$.

\section{RESULTS AND DISCUSSION}

\section{Effect of formaldehyde, acetaldehyde and glutaraldehyde on cell viability in the presence and absence of EDTA} E. coli strain VU3695 and Halomonas MAC tolerated high
formaldehyde concentrations and treatment with
1000 p.p.m. formaldehyde for $1 \mathrm{~h}$ did not cause a marked
decrease in the number of c.f.u. However, when treatment 
Table 1. Influence of sublethal EDTA concentrations on the resistance of E. coli VU3695 and Halomonas MAC to formaldehyde, acetaldehyde and glutaraldehyde

Suspensions of bacteria (about $10^{8}$ cells ml-1) were exposed to different concentrations of aldehydes as indicated, preceded or not preceded by $1 \mathrm{~h}$ incubation with 1.0 or $0.5 \mathrm{mM}$ EDTA, respectively. The number of colony-forming cells (c.f.u.) remaining was determined in triplicate after $1 \mathrm{~h}$. Results are means $\pm \mathrm{sD}$.

\begin{tabular}{|lcc|}
\hline Treatment & Viable counts $\left(\mathbf{l o g}_{10}\right.$ c.f.u. $\left.\mathbf{m l}^{-1}\right)$ \\
\cline { 2 - 3 } & E. coli VU3695 & Halomonas MAC \\
\hline None & $7 \cdot 9 \pm 0 \cdot 3$ & $8 \cdot 1 \pm 0 \cdot 4$ \\
EDTA & $7 \cdot 9 \pm 0 \cdot 2$ & $8 \cdot 1 \pm 0 \cdot 3$ \\
Formaldehyde (25 p.p.m.) & $8 \cdot 0 \pm 0 \cdot 4$ & $8 \cdot 1 \pm 0 \cdot 4$ \\
Formaldehyde (1000 p.p.m.) & $7 \cdot 6 \pm 0 \cdot 3$ & $7 \cdot 6 \pm 0 \cdot 2$ \\
EDTA + formaldehyde (25 p.p.m.) & $6 \cdot 0 \pm 0 \cdot 1$ & $6 \cdot 9 \pm 0 \cdot 2$ \\
EDTA + formaldehyde (1000 p.p.m.) & $0 \cdot 5 \pm 0 \cdot 5$ & $5 \cdot 4 \pm 0 \cdot 1$ \\
Acetaldehyde (15 p.p.m.) & $7 \cdot 9 \pm 0 \cdot 4$ & $8 \cdot 0 \pm 0 \cdot 4$ \\
Acetaldehyde (500 p.p.m.) & $7 \cdot 6 \pm 0 \cdot 1$ & $8 \cdot 1 \pm 0 \cdot 2$ \\
EDTA + acetaldehyde (15 p.p.m.) & $6 \cdot 5 \pm 0 \cdot 4$ & $7 \cdot 5 \pm 0 \cdot 1$ \\
EDTA + acetaldehyde (500 p.p.m.) & $5 \cdot 0 \pm 0 \cdot 4$ & $5 \cdot 0 \pm 0 \cdot 3$ \\
Glutaraldehyde (25 p.p.m.) & $7 \cdot 4 \pm 0 \cdot 3$ & $7 \cdot 6 \pm 0 \cdot 3$ \\
Glutaraldehyde (1000 p.p.m.) & $6 \cdot 3 \pm 0 \cdot 3$ & $6 \cdot 0 \pm 0 \cdot 4$ \\
EDTA + glutaraldehyde (25 p.p.m.) & $5 \cdot 8 \pm 0 \cdot 2$ & $6 \cdot 6 \pm 0 \cdot 2$ \\
EDTA + glutaraldehyde (1000 p.p.m.) & $0 \cdot 5 \pm 0 \cdot 5$ & $1 \cdot 4 \pm 1 \cdot 0$ \\
\hline
\end{tabular}

Table 2. MICs of formaldehyde, acetaldehyde and glutaraldehyde in E. coli VU3695, Halomonas MAC and mutant strains

\begin{tabular}{|lccc|}
\hline \multirow{2}{*}{ Strain } & \multicolumn{3}{c|}{ MIC (p.p.m.) } \\
\cline { 2 - 4 } & Formaldehyde & Acetaldehyde & Glutaraldehyde \\
\hline Halomonas MAC & 55 & 15 & 100 \\
Halomonas MAC-29 & 55 & 15 & 100 \\
Halomonas MAC-6 & 20 & 10 & 50 \\
Halomonas MAC-2 & 25 & 10 & 50 \\
E. coli VU3695 & 150 & 30 & 150 \\
E. coli VU3695-31 & 30 & 10 & 55 \\
E. coli VU3695-21 & 35 & 15 & 60 \\
\hline
\end{tabular}

with formaldehyde (25 or 1000 p.p.m.) was preceded by incubation with sublethal concentrations of EDTA, a reduction in viable counts of 1.9 and $7 \cdot 4 \log _{10}$, respectively, was observed with E. coli, and $1 \cdot 2$ and $2 \cdot 7 \log _{10}$ with Halomonas (Table 1). Addition of EDTA alone did not affect viable counts at the concentrations used. Similar results were obtained when $10 \%$ sucrose was included during the incubation to stabilize the cells. The results of these experiments suggest a possible involvement of the outer membrane in formaldehyde tolerance. EDTA treatment removes divalent cations which are essential for the structural integrity of the outer membrane, and causes the release of part of the lipopolysaccharide layer, thereby increasing the permeability of the outer membrane. Thus,
EDTA treatment enhanced the susceptibility of $E$. coli and other Gram-negative bacteria to several antibiotics (Spicer \& Spooner, 1974; Weiser et al., 1968). EDTA treatment also increased the sensitivity of E. coli VU3695 and Halomonas MAC to acetaldehyde and glutaraldehyde (Table 1).

\section{Formaldehyde tolerance in E. coli VU3695 and Halomonas MAC is not due to formaldehyde dehydrogenase alone}

The presence of high levels of formaldehyde dehydrogenase activity has been implicated in the mechanism of formaldehyde resistance in $E$. coli and other bacteria 


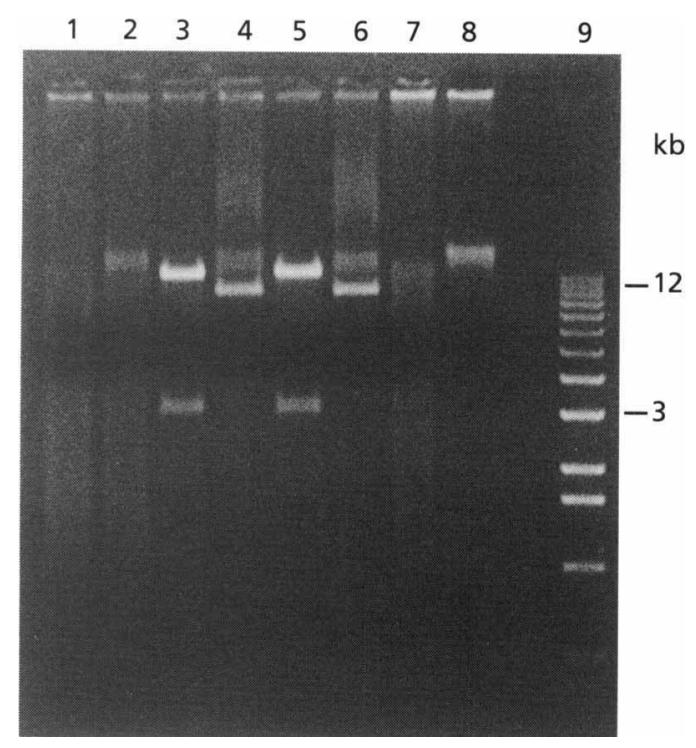

Fig. 1. Agarose gel electrophoresis of intact or Nhel-digested plasmids isolated from Halomonas MAC and its revertants. Lanes: 1 and 2, MAC-6; 3 and 4, MAC-2; 5 and 6, wild-type; 7 and 8, MAC-29; 1, 3, 5 and 7, Nhel-digested; 2, 4, 6 and 8, undigested; 9, DNA ladder.

(Azachi et al., 1995; Kaulfers \& Marquardt, 1991; Kaulfers \& Laufs, 1985). We therefore tested whether treatment with sublethal EDTA concentrations affected formaldehyde dehydrogenase activity. No significant differences were observed in formaldehyde dehydrogenase activity in E. coli VU3695 harvested before and after treatment with $1 \mathrm{mM}$ EDTA [150.3 and $150 \mathrm{nmol}(\mathrm{mg}$ protein $)^{-1} \min ^{-1}$ at $25^{\circ} \mathrm{C}$ ] and in Halomonas with and without $0.5 \mathrm{mM}$ EDTA [ 94.5 and $94 \mathrm{nmol}(\mathrm{mg} \text { protein })^{-1}$ $\mathrm{min}^{-1}$ ]. These results demonstrate that tolerance to high concentrations of formaldehyde cannot be attributed to the presence of high levels of formaldehyde dehydrogenase activity alone.

Additional evidence for the lack of linkage between tolerance to formaldehyde and formaldehyde dehydrogenase activity came from a comparison of the sensitivity of the above strains and revertants to acetaldehyde and glutaraldehyde, two aldehydes that are not oxidized by formaldehyde dehydrogenase. In all cases tolerance toward the three aldehydes was correlated (Table 2), again showing that differences in enzyme activity alone are insufficient to explain differences in aldehyde tolerance.

\section{Formaldehyde tolerance in Halomonas MAC is not plasmid-determined}

Previous studies with E. coli strain VU3695 suggested that its tolerance to formaldehyde is plasmid-mediated, and plasmid-cured cells were found to be formaldehydesensitive (Kaulfers \& Brandt, 1987). Plasmid analysis in Halomonas MAC showed a single band with an apparent size of $15 \mathrm{~kb}$ (Fig. 1). We attempted to transform the $15 \mathrm{~kb}$ plasmid into the formaldehyde-sensitive $E$. coli strains DH5 $\alpha$ and HB101 (Sambrook et al., 1989) and into Halomonas elongata ATCC 33173, which is also formaldehyde-sensitive. pBluescript (Stratagene) was used as a positive control. Transformants were plated onto media (LB agar for E. coli, LB agar supplemented with $10 \% \mathrm{NaCl}$ for Halomonas) containing 50, 75 or 100 p.p.m. formaldehyde. No formaldehyde-resistant transformants were found. This may have been due to one or more of the following reasons: (i) the plasmid does not possess the correct origin of replication; (ii) formaldehyde resistance is not plasmid-mediated; (iii) the gene(s) present on the plasmid are not expressed as proteins.

In order to discriminate between the above possibilities, we attempted to cure Halomonas MAC of its plasmid using a variety of methods (heat and different chemical treatments). Three variant strains were obtained by treatment with novobiocin: MAC-29, a formaldehyde-tolerant strain lacking the plasmid, MAC-6, a formaldehydesensitive strain lacking the plasmid, and MAC-2, a sensitive strain containing the plasmid (Fig. 1). All three revertants possessed formaldehyde dehydrogenase activities similar to that of the wild type $[93 \pm 1 \mathrm{nmol}(\mathrm{mg}$ protein $)^{-1} \mathrm{~min}^{-1}$ ]. Thus, the presence of the plasmid was not necessary for formaldehyde tolerance in Halomonas $\mathrm{MAC}$, and formaldehyde dehydrogenase activity is probably not mediated by the $15 \mathrm{~kb}$ plasmid.

Using ethidium bromide mutagenesis of E. coli VU3695 we isolated two formaldehyde-sensitive revertants (strains 31 and 21). These revertants contained the plasmid of the parent strain, but lacked formaldehyde dehydrogenase activity. Interestingly, using the same procedure as Kaulfers \& Brandt (1987), we have observed loss of formaldehyde dehydrogenase activity in the presence of the plasmid. It should be noted that ethidium bromide is a mutagenic agent that may damage gene activity both in the chromosome and in the plasmid. Therefore, it cannot be ascertained whether the gene(s) that confer formaldehyde resistance in E. coli VU3695 are plasmid-linked or chromosomal.

\section{Formaldehyde tolerance in E. coli VU3695 and Halomonas MAC involves the outer membrane}

The outer membrane is the first barrier encountered by formaldehyde to penetration of Gram-negative bacteria. We therefore investigated whether differences in formaldehyde tolerance of the strains and their sensitive revertants was correlated with differences in the structure of their outer membranes. The outer membrane preparations obtained were found to be free of formaldehyde dehydrogenase activity, showing that contamination with cytoplasmic proteins was insignificant. As in other Gramnegative bacteria (Lidstrom, 1992), the formaldehydeoxidizing activity in Halomonas MAC and E. coli VU3695 was found to be located in the cytoplasmic fraction. Comparison of the outer membrane protein profile of $E$. coli VU3695 and its formaldehyde-sensitive revertants 31 and 21 showed that an additional high-molecular-mass protein (apparent molecular mass $>143 \mathrm{kDa}$ ) was present in the wild-type strain, but missing in both 


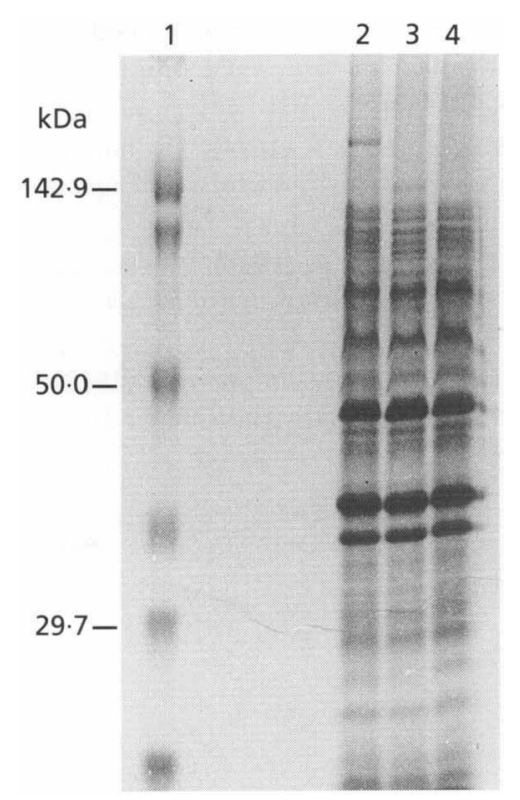

Fig. 2. SDS-PAGE of outer membrane proteins of $E$. coli VU3695 (lane 2) and revertants 31 (lane 3) and 21 (lane 4). Lane 1 contains molecular mass standards.

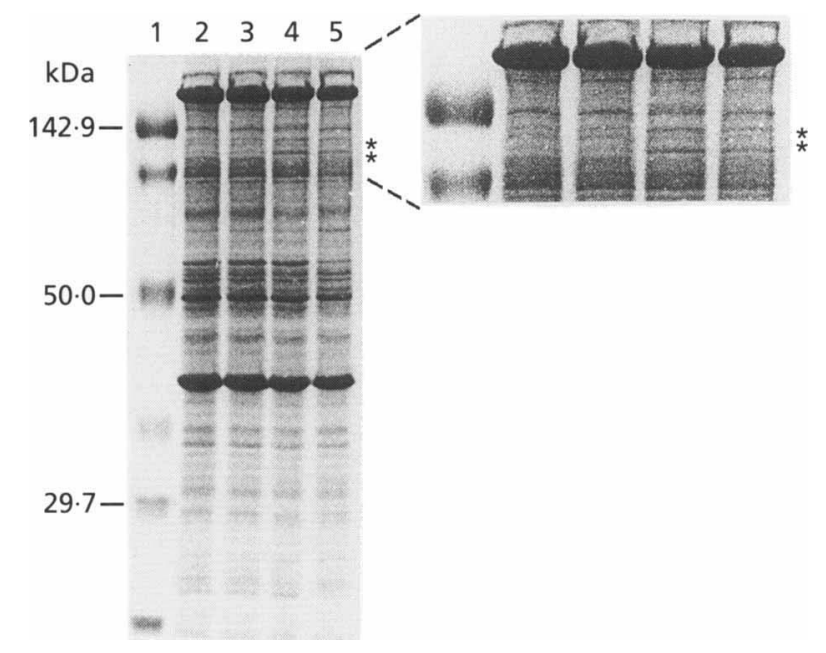

Fig. 3. SDS-PAGE of outer membrane proteins of Halomonas MAC (lane 5) and revertants 2 (lane 2), 6 (lane 3) and 29 (lane 4). Lane 1 contains molecular mass standards.

sensitive revertants (Fig. 2). In Halomonas MAC, two proteins (apparent molecular mass $98-143 \mathrm{kD}$ ) were prominent in both the wild-type and in strain MAC-29 (formaldehyde-tolerant, lacking the plasmid), but were present in reduced amounts in the formaldehyde-sensitive revertants MAC-6 and MAC-2 (Fig. 3).

The above data indicate the importance of the outer membrane as the barrier that protects the cell from formaldehyde, and show that unique proteins may participate in conferring formaldehyde resistance. To some extent the above findings are surprising, as a molecule as small as formaldehyde would be expected to penetrate the outer membrane through porins. We are currently investigating the properties of the proteins involved and the corresponding genes in order to elucidate their function in formaldehyde resistance. We expect that further characterization of the above-described mutants may lead to the identification of the gene(s) involved in formaldehyde tolerance, and an in-depth understanding of the phenomenon. We recently initiated a study to identify and characterize the relevant genes by using random mutagenesis of the resistant mutant MAC-29, lacking the plasmid, with transposon Tn5. A number of formaldehyde-sentitive mutants were obtained, which did show formaldehyde dehydrogenase activity, but lacked the $\sim 98 \mathrm{kDa}$ protein in their outer membrane (results not shown). One of these mutants was shown to contain a single copy of Tn5. Further characterization of this mutant is in progress.

\section{ACKNOWLEDGEMENTS}

We thank H. Volpin for assistance with the Tn 5 studies and P. M. Kaulfers (University of Hamburg) for the gift of $E$. coli VU3695.

\section{REFERENCES}

Azachi, M., Henis, Y., Oren, A., Gurevich, P. \& Sarig, S. (1995). Transformation of formaldehyde by a Halomonas sp. Can J Microbiol 41, 548-553.

Birnboim, H. C. \& Doly, J. (1979). A rapid alkaline extraction procedure for screening recombinant plasmid DNA. Nucleic Acids Res 7, 1513-1523.

Bradford, M. M. (1976). A rapid and sensitive method for the quantitation of microgram quantities of protein using the principle of protein-dye binding. Anal Biochem 72, 248-254.

Diver, M. D., Larry, E. B. \& Pamela, A. S. (1990). Transformation of Pseudomonas aeruginosa by electroporation. Anal Biochem 189, 75-79.

Hancock, R. E. W. \& Carey, A. M. (1979). Outer membrane of Pseudomonas aeruginosa: heat and 2-mercaptoethanol-modifiable proteins. J Bacteriol 140, 902-910.

Hancock, R. E. W. \& Nikaido, H. (1978). Outer membranes of gramnegative bacteria. XIX. Isolation from Pseudomonas aeruginosa $\mathrm{P} \Lambda \mathrm{O} 1$ and use in reconstitution and definition of the permeability barrier. $J$ Bacteriol 136, 381-390.

Kato, N., Kobayashi, H., Shimao, M., \& Sakazawa, C. (1984). Properties of formaldehyde dismutation catalyzing enzyme of Pseudomonas putida F61. Agric Biol Chem 48, 2017-2023.

Kato, N., Yamagami, N., Shimao, M. \& Sakazawa, C. (1986). Formaldehyde dismutase, a novel NAD-binding oxidoreductase from Pseudomonas putida F61. Eur J Biochem 156, 59-64.

Kato, N., Miyamoto, N., Shimao, M. \& Sakazawa, C. (1988). 3 Hexulose phosphate synthase from a new facultative methylotroph, Mycobacterium gastri MB19. Agric Biol Chem 52, 2659-2661.

Kaulfers, P. M. \& Brandt, D. (1987). Isolation of a conjugative plasmid in Escherichia coli determining formaldehyde resistance. FEMS Microbiol Lett 43, 161-163.

Kaulfers, P. M. \& Laufs, R. (1985). Übertragbare Formaldehydresistenz bei Serratia marcescens. Zentralbl Bakteriol Mikrobiol Hyg I Abt Orig B 181, 309-319. 
Kaulfers, P. M. \& Marquardt, A. (1991). Demonstration of formaldehyde dehydrogenase activity in formaldehyde-resistant Enterobacteriaceae. FEMS Microbiol Lett 79, 335-338.

Lidstrom, M. E. (1992). The aerobic methylotrophic bacteria. In The Prokaryotes. A Handbook on the Biology of Bacteria: Ecophysiology, Isolation, Identification, Applications, pp. 431-445. Edited by A. Balows, H. G. Trüper, M. Dworkin, W. Harder \& K.-H. Schleifer. New York: Springer-Verlag.

Lieve, L. (1974). The barrier function of the gram-negative cell envelope. Ann NY Acad Sci 235, 109-127.

McGavin, M., Lam, J. \& Forsberg, C. W. (1990). Regulation and distribution of Fibrobacter succinogenes subsp. succinogenes $\mathrm{S} 85$ endoglucanases. Appl Environ Microbiol 56, 1235-1244.

Nikaido, H. \& Vaara, M. (1985). Molecular basis of bacterial outer membrane permeability. Microbiol Rev 49, 1-32.
Sambrook, J., Fritsch, E. F. \& Maniatis, T. (1989). Molecular Cloning: a Laboratory Manual, 2nd edn. Cold Spring Harbor, NY: Cold Spring Harbor Laboratory.

Spicer, A. B. \& Spooner, D. F. (1974). The inhibition of growth of Eschericbia coli spheroplasts by antibacterial agents. J Gen Microbiol 80, 37-50.

Wang, W. \& Thomson, J. A. (1990). Nucleotide sequence of the cel $A$ gene encoding a cellodextrinase of Ruminococcus flavefaciens. Mol Gen Genet 222, 265-269.

Weiser, R., Asscher, A. W. \& Wimpenny, J. (1968). In vitro reversal of antibiotic resistance by ethylendiamine tetraacetic acid. Nature 219, 1365-1366.

Received 1 November 1995; revised 15 December 1995; accepted 19 December 1995. 